\title{
Constructive Optimism, Defensive Optimism, and Gender as Predictors of Autonomous Motivation to Follow Stay-at-Home Recommendations During the COVID-19 Pandemic
}

\author{
Tamara O. Gordeevaa, ${ }^{\mathrm{a}, \mathrm{d}}$, Oleg A. Sychev $\mathrm{v}^{\mathrm{b}}$, Yuri I. Semenov ${ }^{\mathrm{c}}$ \\ ${ }^{a}$ Faculty of Psychology, Lomonosov Moscow State University, Moscow, Russia \\ ${ }^{\mathrm{b}}$ Altai State University for Humanities, Biysk, Russia \\ ${ }^{c}$ Academy of Sciences of the Republic of Sakha, Yakutia, Yakutsk, Russia \\ ${ }^{\mathrm{d}}$ Higher School of Economics, Moscow, Russia
}

*Corresponding author. E-mail: osn1@mail.ru

Background. This study is based on self-determination theory and the research on dispositional optimism and unrealistic optimism. Dispositional optimism is known to be protective of well-being and is related to adaptive coping strategies. Investigations related to unrealistic optimism, on the other hand, revealed that it may have both positive and negative consequences.

Objective. To investigate dispositional optimism and two kinds of specific optimism as predictors of autonomous motivation to follow stay-at-home orders during the COVID-19 pandemic in a sample of Russian young adults: constructive optimism, meaning belief in the role of effort; and defensive optimism, meaning unrealistic expectations and denial that a problem exists.

Design. A correlational (cross-sectional) study was conducted to measure adherence to the recommendation to stay at home, autonomous motivation, dispositional optimism, constructive optimism, and defensive optimism. An online survey was completed by 1,403 young adults ( $68 \%$ women) during the first month of lockdown.

Results. The findings demonstrate that constructive optimism and its underlying dispositional optimism predict both autonomous motivation and adherence to the recommendation to stay at home, while defensive optimism produces the opposite, undermining effects. Structural equation modeling revealed the effect of gender on adherence to the recommendation (higher in women), mediated by different types of optimism and autonomous motivation.

Conclusion. Dispositional optimism together with situation-specific constructive and defensive types of optimism are essential for explaining the health-related behavior and its motivation. These results contribute to self-determination theory, considering the role of personality factors in determining motivation.

Keywords:

COVID-19 pandemic, constructive optimism, defensive optimism, dispositional optimism, autonomous motivation, stay-at-home orders, gender, well-being 


\section{Introduction}

The coronavirus outbreak that started in December 2019 has caused significant disruptions to people's lives around the world. The seriousness of the risk, unpredictability of the situation, and uncertainty about how to control the disease make the situation especially stressful. The COVID-19 pandemic has led many countries to implement lockdowns. While lockdowns help to contain the spread of the virus, research in many countries shows that they also result in substantial damage to well-being and mental health (Agteren et al., 2020; Ahmed et al., 2020; Balkhi, Nasir, Zehra, \& Riaz, 2020; Brodeur, Clark, Fleche, \& Powdthavee, 2020; Brooks et al., 2020; Bu, Hanspal, Liao, \& Liu, 2020; Globig, Blain, \& Sharot, 2020; Huang \& Zhao, 2020; Lei et al., 2020; Pervichko, Mitina, Stepanova, Koniukhovskaia, \& Dorokhov, 2020; Solomou \& Constantinidou, 2020; Stanton et al., 2020; Wang et al., 2020). For example, findings from researchers in China, the country which faced the COVID-19 first, have shown a prevalence of depression during quarantine up to $37 \%$ (Ahmed et al., 2020), and a prevalence of anxiety up to 35\% (Huang \& Zhao, 2020). In particular, a comparison study found significant differences in the prevalence of depression and anxiety between people in quarantine and people not in quarantine (Lei et al., 2020). Similarly, a recent Australian study (Agteren et al., 2020) demonstrated significantly worse outcomes on all mental health measures for participants measured during COVID-19, compared to those measured before ( $p \leq .001$ for all outcomes, effect sizes ranging between $d=.32$ to $d=.81$ ). Research on Google Trends in Europe and the US (Brodeur et al., 2020) found a substantial increase in the search intensity for boredom, loneliness, worry, and sadness. Most research shows increase in anxiety, depression, and sleep disturbance. The reported increase in mental health issues due to physical distancing, quarantine, and social isolation makes further research in this area critical in order to identify groups at risk and to tailor appropriate interventions.

While most results suggest that people's mental health may have been severely affected by the lockdown and social control mechanisms, there are also some promising findings regarding quarantine's effects on mental health. First, not everyone experienced significant deterioration in mental health, including stress, anxiety, depression, and loneliness. Second, it seems that psychological well-being was only partly affected by the pandemic and lockdown. For example, studying a Russian sample, Rasskazova and colleagues (2020) have shown that life satisfaction and positive and negative emotions remained stable during the spring 2020 pandemic compared to previous years. Third, it seems that most people have adapted to the quarantine. Globig, Blain, and Sharot (2020) found that anxiety was significantly lower one month into lockdown relative to the beginning of lockdown, and people reported an increase in their sense of agency; optimism and happiness remained stable.

The only study on psychological predictors of positive behavior change (e.g., social distancing, improved hand hygiene) during the COVID-19 pandemic showed the role of fear of the virus in public health compliance (Harper, Satchell, Fido, \& Latzman, 2020). It is unclear whether positive attitudes and beliefs matter. 


\section{Psychological and Demographic Factors Related to Stress and Declining Mental Health During the Pandemic}

\section{Psychological Factors}

It is possible that the effects of lockdown are mediated by people's perception of the severity of the situation and specific cognitive strategies and personality variables, such as optimistic expectations and resilience. Optimism, hope, and self-efficacy are three cognitive variables representing positive expectations that proved to protect against development of PTSD (Gallagher, Long, \& Phillips, 2020) and which may be helpful in overcoming psychological consequences of COVID-19-related stress. We found two studies which examined different types of optimism in the context of COVID-19-related stress and well-being (Arslan \& Yildirim, 2020; Globig et al., 2020).

Globig, Blain \& Sharot (2020) discovered that optimism regarding the COVID-19 pandemic was associated with people's positive feelings and this association was mediated by people's sense of agency over their future. Arslan and Yildirim's study (2020) indicated that optimistic cognitions and psychological inflexibility mediated the effect of coronavirus stress on psychological problems. However, we found no research on the role of constructive and inflexible optimism ("rose-colored glasses") and its role in well-being during the pandemic.

\section{Gender and Other Demographic Factors}

Most studies show the effect of gender (female), age (Solomou \& Constantinidou, 2020), health problems (de Pedraza, Guzi, \& Tijdens, 2020), and low income (Bu et al., 2020) on well-being during the COVID-19 pandemic. Studies on different samples have shown that women are especially vulnerable to COVID-related anxiety and depression (Adams-Prassl, Boneva, Golin, \& Rauh, 2020; de Pedraza et al., 2020; Pervichko et al., 2020; Rasskazova, Leontiev, \& Lebedeva, 2020; Solomou \& Constantinidou, 2020; Stanton et al., 2020; Wang et al., 2020). This may be related to less tolerance of stress and less productive coping strategies during the COVID-19 pandemic displayed by women. Indeed, Rasskazova and colleagues (2020) have shown that women were less prone to use active coping strategies and humor during the pandemic; these strategies were related to higher well-being and better mental health.

\section{Optimism, Well-Being, and Health-Related Outcomes}

Our research is concentrated on different types of optimism as factors that promote adherence to the recommendation to stay at home during the self-isolation (quarantine) period, which was intended to protect health-related outcomes. Optimism represents trait-like positive expectancies conceptualized in the context of goal-directed behavior. Scheier and Carver (1985) define dispositional optimism as a personality trait representing the tendency to anticipate favorable outcomes to events. It is an important predictor of well-being and life satisfaction, and is associated with lower levels of anxiety and depression (Andersson, 1996; Carver \& Scheier, 2014) and better physical health and longevity (Carver, Scheier, \& Segerstrom, 2010; Taylor, Kemeny, Reed, Bower, \& Gruenewald, 2000). Optimism en- 
hances people's motivation to pursue goal-oriented behaviors (Scheier \& Carver, 1985 ) and is related to better subjective well-being in times of adversity (Carver et al., 2010).

Optimistic individuals have been reported to employ more approach coping strategies aiming to reduce, eliminate, or manage stressors or emotions, and fewer avoidance coping strategies seeking to avoid, ignore, or withdraw from stressors or emotions (Nes \& Segerstrom, 2006). A recent meta-analysis shows that positive expectancies may protect against the development of posttraumatic stress disorder (PTSD) (Gallagher et al., 2020). Thus, dispositional optimism acts as a motivational mechanism important to mobilize cognitive and affective resources associated with well-being.

Since people are prone to be optimistic about life events, especially those happening in their own lives (Seligman, 2011; Sharot, 2012), they can sometimes rely on optimism too much. For example, some people "wear rose-colored glasses" and display unrealistic optimism. Goleman (1989) considers the individual's optimistic capacity for self-deception as a survival mechanism, which plays a vital role in the psyche of the healthy person. The function of denial is to soothe, maintain illusions, and promote well-being. Although positive illusions and expectations are prevalent in normal life and are often considered useful in some cases for maintaining a healthy mental state (Taylor et al., 2000), there is serious disagreement about whether they are beneficial or not. Colvin and Block (1994) conclude that it remains unproven whether unrealistic optimism, unrealistically positive views of the self, and illusions of control - three key positive illusions - foster mental health. Despite some new data showing that positive illusions, including self-enhancement and favorable comparisons with others, are related to high subjective well-being and low depressiveness (Dufner, Gebauer, Sedikides, \& Denissen, 2019), we did not find strong empirical support for the health benefits of unrealistically positive expectations about the life-threatening events that are the object of our study.

\section{Specific Types of Optimism: Constructive and Defensive Optimism}

Dispositional optimism refers to stable personality characteristics that have important implications for regulating one's behaviors and maintaining well-being. Research suggests that specific types of optimism may be better predictors of COVID19-related mental health outcomes (Globig et al., 2020) and behavior in stressful situation (Gassman, 2019) than is dispositional optimism. Gallaher et al.s metaanalysis (2020) of positive expectations revealed that generalized self-efficacy has a weaker relationship with PTSD than specific self-efficacy. In the present research, we distinguish two specific types of optimism related to perception of threatening life events (the COVID-19 pandemic) - constructive optimism and defensive optimism.

Defensive optimism is a tendency to believe that the situation is not as bad as others (realistically) present it. Defensive optimism is similar to minimization, which is considered a type of cognitive distortion in cognitive-behavioral therapy; it is the opposite of exaggeration (Helmond, Overbeek, Brugman, \& Gibbs, 2015). Minimization, or downplaying the significance of an event or emotion, is a com- 
mon strategy for dealing with negative feelings such as guilt (Hoyk \& Hersey, 2010). Defensive optimism is also close to self-deception involving denial.

Defensive optimism has a counterpart called defensive pessimism (Norem, 2008; Norem \& Cantor, 1986); people use defensive pessimism as a strategy to prepare for anxiety-provoking events or performances. We suggest that both defensive pessimism and defensive optimism are motivated by anxiety. However, whereas the negative possible outcomes of a situation often motivate defensive pessimists to work harder for successful results, the prediction of positive outcomes does not motivate defensive optimists to take additional actions that may help to promote health-promoting false calm.

Whereas defensive optimism is an unrealistic belief in a positive future and/or optimistic expectancy of positive outcomes higher than the objective probability would warrant, constructive optimism refers to the belief in the role of effort, with a sense of control (Langer, 1975). Due to real persistence, constructive optimism may effectively prevent the spread of the virus. Both types of optimism deal with overcoming stressful situations, but constructive optimists acquire a sense of control and agency, believing in the role of efforts, whereas defensive pessimists seemingly succeed in coping with the anxiety related to uncontrollable events.

\section{Autonomous and Controlled Motivation of Healthy Behavior}

Any purposeful behavior implies the presence of motivation, including behavior associated with following the rules of quarantine and self-isolation. Self-Determination Theory (SDT) is one of the most influential contemporary theories of human motivation, which has successful applications in basically all domains of human life, including health and following a doctor's orders (Ryan \& Deci, 2017). According to SDT, motivation differs not only in quantity, but also in quality, where "quality" refers to the relative degree of autonomy or self-determination (Ryan \& Deci, 2000). Autonomous motivation comprises both intrinsic motivation and the types of extrinsic motivation in which people have identified with an activity's value and have integrated it into their sense of self. Conversely, controlled motivation consists of both introjected regulation, in which the regulation of action has been partially internalized and is energized by factors such as avoidance of shame and guilt, contingent self-esteem, pride, and external regulation, in which one's behavior is a function of external contingencies of reward, approval, or punishment.

In the health domain, it has been shown that autonomous forms of motivation are generally more effective in predicting health behavior than controlled forms (Hagger et al., 2014). Being autonomously motivated can promote engagement in and maintenance of health behaviors (Deci \& Ryan, 2000; Ng et al., 2012; Patrick \& Williams, 2012). Autonomous motivation has been positively associated with oral health behaviors (brushing and flossing one's teeth) (Halvari \& Halvari, 2006), exercise and weight loss (Silva et al., 2011), healthy eating behavior (fruit/vegetable intake) (Dwyer et al., 2017; McSpadden et al., 2016; Shaikh, Yaroch, Nebeling, Yeh, \& Resnicow, 2008), and it can predict health-related behaviors among adolescents, such as more physical activity and less marijuana use, smoking, and sexual intercourse (Gillison, Sebire, \& Standage, 2012; Hardy, Dollahite, Johnson, \& Christensen, 2015; Verloigne et al., 2011). 
As to personality variables that predict autonomous motivation of healthy behavior, research to date is scarce. One study found that domain-specific optimism - optimism for the specific purpose of engaging in exercise - proved to be one of the best predictors of exercise engagement after autonomous motivation, whereas dispositional optimism was not related to exercise engagement and autonomous motivation (Gassman, 2019).

We hypothesized that defensive COVID-19-related optimism could have harmful consequences, undermining autonomous motivation to follow the recommendation to stay at home during a quarantine period. In particular, the effort to maintain healthy behavior during a pandemic can decrease if a person believes that the situation is not dangerous.

\section{Methods}

Given the theoretical and empirical evidence presented above, the purpose of the current study was to examine the mediating effects of the two types of specific optimism (constructive and defensive) and of autonomous motivation on the healthsupportive behavior of Russian young adults, with respect to adherence to the recommendation to stay at home.

Prior to testing the mediation model, we first examined the psychometric properties of a new measure, the Constructive-Defensive Optimism Questionnaire (CODOQ), to enhance the scale's usability for both research and practice using the sample of the present study. Subsequently, we addressed the following specific research hypotheses:

H1: Constructive optimism would be positively associated with dispositional optimism and well-being, whereas defensive optimism would be negatively associated with dispositional optimism;

H2: Autonomous motivation would mediate the positive impact of constructive optimism on staying-at-home behavior;

H3: Autonomous motivation would mediate the negative impact of defensive optimism on staying-at-home behavior;

H4: In accordance with our previous research on dispositional optimism in Russian samples (Gordeeva, Sychev, \& Osin, 2021), we expected that women would display higher dispositional optimism and constructive optimism than men.

\section{Participants and Procedure}

Participants were 1,403 students from different universities in two large cities in the Far East of Russia and the Urals. The sample comprised 956 (68\%) women and 447 men, age $M=20.59, S D=3.66$. Participants completed a battery of questionnaires online. The study started on April 10,2020, two weeks after the introduction of the self-isolation mode (lockdown) in Russia (March 25, 2020), and ended on April 25, 2020.

\section{Measures}

Development of the Constructive and Defensive Optimism measure. Based on the construct's definition and prior literature, a pool of six face-valid items was 
generated to assess constructive and defensive optimism during the coronavirus pandemic. The content of the items reflects 1) the importance of efforts for coping with problems caused by the pandemic, along with the flexible view of the current situation typical of constructive optimism, and 2) defensive denial, including "positive" underestimation of the problem (similar to "rose-colored glasses") (see items of the questionnaire in Table 1). All items were rated on a Likert-type scale ranging from 1 (absolutely do not agree) to 5 (totally agree). The reliability coefficients (Cronbach's $\alpha$ ) for all scales used in this study are presented in Table 2.

Dispositional optimism was assessed by the Russian version of the Life Orientation Test-Revised (Gordeeva et al., 2021; Scheier, Carver, \& Bridges, 1994). This measure includes three positively worded items, three negatively worded items, and six filler items, rated on a scale from 0 (strongly disagree) to 4 (strongly agree).

Motivation to adhere to recommendations was measured with a questionnaire based on the UPLOC developed by SDT researchers (Sheldon, Osin, Gordeeva, Suchkov, \& Sychev, 2017). This version of the questionnaire consists of one main question regarding the reasons for following the recommendations ("Please explain the reasons why you are following these recommendations (at least to a small extent)." "I plan to follow the recommendations and stay at home as much as possible, because...") and two subscales, each with 4 items, measuring autonomous and controlled motivation. Examples of the items are: "The recommendations reflect my values" (autonomous motivation) and "I don't want to be criticized for not following the recommendations" (controlled regulation). Respondents rated their agreement with each item on a scale from 1 (not at all true) to 7 (very true).

Adherence to the recommendation was measured with a single item asking about how much the person adheres to the recommendation to stay at home. Participants chose from 1 (not at all) to 7 (totally follow this recommendation).

To establish construct validity of the specific optimism measure, we used three additional well-being questionnaires. Life satisfaction and happiness were measured with Russian versions (Osin \& Leontiev, 2020) of the Satisfaction with Life Scale (SWLS; Diener, Emmons, Larsen, \& Griffin, 1985) and the Subjective Happiness Scale (SHS; Lyubomirsky \& Lepper, 1999). The SWLS consists of five items which were rated on a scale from 1 (strongly disagree) to 5 (strongly agree), and the SHS consists of four items rated on a 7-point scale. Emotional well-being was assessed using the Russian version of the Positive and Negative Affect Schedule (Osin, 2012; Watson, Clark, \& Tellegen, 1988), which consists of two 10-item scales to measure both positive and negative affect over the last week. Each item is rated on a scale from 1 (not at all) to 5 (very much).

\section{Data Analysis}

Structural equation modeling was undertaken in Mplus 8, using robust maximum likelihood estimation (MLR). To assess the significance of mediated effects in the structural model, the bootstrap method, with 5,000 samples, was used in Mplus (Muthén \& Muthén, 2015). Other analyses, including descriptive statistics, correlations analysis, exploratory factor analysis (EFA), and t-tests were carried out using R. 


\section{Results}

\section{Preliminary Analysis of the New Measure of Constructive and Defensive Optimism}

To test the structure of the new measure of constructive and defensive optimism, we implemented EFA using the "minimum residuals" estimation method and parallel analysis for assessing the number of factors. The KMO measure of sampling adequacy $(\mathrm{KMO}=.69)$ and Bartlett's test of sphericity $\left.\chi^{2}(15)=1,859.74, p \leq .001\right)$ both indicated that it was appropriate to apply factor analysis to this set of data. Two moderately correlated factors $(r=.20)$ were extracted, which explained $48 \%$ of the total variance. Factor loadings after "oblimin" rotation, presented in Table 1, show that the empirical structure of the questionnaire corresponded to the hypothesized structure.

Table 1

Results of the exploratory factor analysis of the new measure of constructive and defensive optimism $(N=1,403)$

\begin{tabular}{lcc}
\hline \multicolumn{1}{c}{ Items } & \multicolumn{2}{c}{ Factor loading } \\
\cline { 2 - 3 } & Factor 1 & Factor 2 \\
\hline $\begin{array}{l}\text { 1. I believe that by making efforts, we can improve the situation } \\
\text { and find optimal solutions to problems. }\end{array}$ & .00 & .78 \\
$\begin{array}{l}\text { 2. I think that everyone is exaggerating; in fact, this virus is not as } \\
\text { dangerous as they say. }\end{array}$ & .81 & -.02 \\
$\begin{array}{l}\text { 3. I think that now we must hope for the best, but prepare for the } \\
\text { worst and remain calm. }\end{array}$ & -.01 & .55 \\
$\begin{array}{l}\text { 4. The people around me and the media overstate the problem; in } \\
\text { fact, everything will be fine. }\end{array}$ & .69 & .08 \\
$\begin{array}{l}\text { 5. I believe that our efforts can help prevent the spread of the dis- } \\
\text { ease. }\end{array}$ & .00 & .66 \\
$\begin{array}{l}\text { 6. In the current situation, we have nothing to worry about; I do } \\
\text { not see any real danger. }\end{array}$ & .62 & -.08 \\
$\begin{array}{l}\text { Eigenvalues } \\
\text { Percentage of explained variance }\end{array}$ & 1.52 & 1.37 \\
\hline
\end{tabular}

Further, we tested the fit of the model with two correlated factors using CFA. Cross loadings and covariances between items were not allowed. The results of analysis indicated a good fit of this model: $\chi^{2}=27.11, d f=8, p \leq .001$, CFI $=.985$, $\mathrm{TLI}=.971, \mathrm{RMSEA}=.041(90 \% \mathrm{CI}=[.025, .059])$, PCLOSE $=.777, N=1,403$. All factor loadings were higher than .55 and significant at $p \leq .001$; correlation between latent factors was $-.28(p \leq .001)$. The reliability coefficients (Cronbach's $\alpha$ ) of scales were .70 for constructive optimism and .75 for defensive optimism.

The construct validity of the scales of constructive and defensive optimism is confirmed by the correlations with well-being indicators (see Table 2). As expected, constructive optimism showed weak positive correlations with indicators 
of well-being such as positive affect, satisfaction with life, and subjective happiness ( $r$ from .12 to .17; both at $p \leq .001$ ), while defensive optimism did not correlate with any indicators of well-being ( $r$ from -.02 to .03 ; none are significant). These results indicate that constructive optimism may help to maintain a higher level of wellbeing during a pandemic, but defensive optimism, as a relatively ineffective type of coping with problems, is irrelevant for well-being. Accordingly, we found the opposite correlations of dispositional optimism with constructive $(r=.25 ; p \leq .001)$ and defensive optimism $(r=-.07 ; p \leq .01)$, which confirms that the last two constructs are completely different in nature.

\section{Correlations of Different Types of Optimism with Health-Related Variables and Gender}

Health-related variables showed the expected correlations with these two specific types of optimism (see Table 2). In particular, constructive optimism was moderately positively associated with autonomous motivation $(r=.45 ; p \leq .001)$ and adherence to recommendations $(r=.28 ; p \leq .001)$. The opposite, negative correlations, were found between defensive optimism and autonomous motivation $(r=-.29 ; p \leq .001)$ and adherence to recommendations $(r=-.15 ; p \leq .05)$. In addi-

\section{Table 2}

Descriptive statistics and correlations between different types of optimism, motivation, adherence to recommendations and well-being $(N=1,403)$

\begin{tabular}{|c|c|c|c|c|c|c|c|c|c|c|c|c|c|}
\hline & $\alpha$ & Mean & $S D$ & 1 & 2 & 3 & 4 & 5 & 6 & 7 & 8 & 9 & 10 \\
\hline $\begin{array}{l}\text { 1. Constructive } \\
\text { optimism }\end{array}$ & .70 & 4.00 & 0.83 & 1 & $-.20^{\star \star \star}$ & $.24^{\star * *}$ & $.44^{\star * \star}$ & .03 & $.26^{* * *}$ & $.12^{\star \star \star}$ & $-.07^{\star \star}$ & $.16^{\star * *}$ & $.16^{* * *}$ \\
\hline $\begin{array}{l}\text { 2. Defensive } \\
\text { optimism }\end{array}$ & .75 & 2.48 & 0.9 & $-.20^{\star * *}$ & 1 & $-.06^{\star}$ & $-.28^{* * *}$ & $.15^{\star \star *}$ & $-.14^{\star * *}$ & .01 & -.01 & .02 & .01 \\
\hline $\begin{array}{l}\text { 3. Disposition- } \\
\text { al optimism }\end{array}$ & .78 & 2.43 & 0.73 & $.25^{\star * *}$ & $-.07^{\star \star}$ & 1 & $.17^{\star * *}$ & $-.13^{\star * \star}$ & $.08^{\star *}$ & $.37^{\star * *}$ & $-.29^{\star \star *}$ & $.41^{\star * *}$ & $.55^{\star \star \star}$ \\
\hline $\begin{array}{l}\text { 4. Autonomous } \\
\text { motivation }\end{array}$ & .81 & 5.46 & 1.42 & $.45^{\star * *}$ & $-.29^{\star \star \star *}$ & $.20^{* * *}$ & 1 & $.26^{\star * *}$ & $.41^{* * *}$ & $.14^{* * *}$ & -.02 & $.16^{* * *}$ & $.14^{\star \star \star}$ \\
\hline $\begin{array}{l}\text { 5. Controlled } \\
\text { motivation }\end{array}$ & .73 & 3.71 & 1.66 & .03 & $.15^{\star * *}$ & $-.13^{\star \star *}$ & $.25^{\star \star \star}$ & 1 & $.09^{\star * *}$ & -.05 & $.11^{\star * *}$ & 0.00 & $-.10^{\star * *}$ \\
\hline $\begin{array}{l}\text { 6. Adherence } \\
\text { to recom- } \\
\text { mendations }\end{array}$ & - & 6.15 & 1.25 & $.28^{* * *}$ & $-.15^{\star * *}$ & $.06^{*}$ & $.40^{* * *}$ & $.09^{* * *}$ & 1 & $.05^{\star}$ & $-.07^{\star}$ & $.11^{\star * *}$ & $.06^{*}$ \\
\hline $\begin{array}{l}\text { 7. Positive } \\
\text { affect }\end{array}$ & .89 & 2.98 & 0.77 & $.12^{\star * *}$ & .01 & $.37^{\star * *}$ & $.14^{* * *}$ & -.05 & $.06^{*}$ & 1 & $-.50^{\star * *}$ & $.45^{\star * *}$ & $.52^{\star \star \star}$ \\
\hline $\begin{array}{l}\text { 8. Negative } \\
\text { affect }\end{array}$ & .88 & 2.58 & 0.84 & -.05 & -.02 & $-.31^{\star \star \star}$ & -.04 & $.11^{\star \star \star}$ & -.05 & $-.49^{* * *}$ & 1 & $-.35^{\star * *}$ & $-.47^{\star * *}$ \\
\hline $\begin{array}{l}\text { 9. Satisfaction } \\
\text { with life }\end{array}$ & .80 & 3.26 & 0.73 & $.15^{\star * *}$ & .03 & $.42^{\star * *}$ & $.17^{\star \star \star}$ & .00 & $.11^{* * *}$ & $.45^{\star * *}$ & $-.35^{\star \star \star}$ & 1 & $.57^{\star * *}$ \\
\hline 10. Happiness & .76 & 4.24 & 1.27 & $.17^{\star * *}$ & .01 & $.55^{\star * *}$ & $.14^{* * *}$ & $-.10^{* * *}$ & $.07^{\star}$ & $.52^{* * *}$ & $-.46^{\star * *}$ & $.57^{\star * *}$ & 1 \\
\hline
\end{tabular}

Note. The correlations controlled for gender are presented above the diagonal; the zero-order correlations are presented below the diagonal; ${ }^{\star} p \leq .05,{ }^{* *} p \leq .01,{ }^{* * *} p \leq .001 ; \alpha=$ Cronbach's $\alpha$. 
tion, defensive optimism demonstrated weak positive correlation with controlled motivation $(r=.15 ; p \leq .001)$.

Participants reported significantly higher autonomous motivation to follow stay-at-home recommendations $(M=5.46, S D=1.42)$ compared to their controlled motivation $(M=3.71, S D=1.66)$, and both types of motivation were related to stay-at-home behavior, with much stronger correlation in the former case $(r=.40 ; p \leq .001)$.

Analysis of differences between men and women using Welch's $t$-test (see Table 3) demonstrated that women were more prone to follow the recommendation to stay at home (at $p \leq .001$ ), and were also higher in constructive optimism, dispositional optimism, and autonomous motivation (all $p \leq .001$ ), while men were slightly higher than women in defensive optimism $(p \leq .05)$. Most of these differences were small; however, the effect of gender on autonomous motivation was medium (Cohen's $d=.45$ ).

Given that many study variables turned out to be dependent on gender, we included it as a controlled variable in all statistical analyses. Correlations among study variables controlling for gender (see Table 2, above the diagonal) were close to the zero-order correlations.

\section{Table 3}

Gender differences in different types of optimism, motivation, adherence to recommendations, and well-being

\begin{tabular}{|c|c|c|c|c|c|c|c|c|}
\hline & \multicolumn{2}{|c|}{ Means } & \multicolumn{2}{|c|}{ SD } & \multirow[b]{2}{*}{$\begin{array}{l}\text { Welch's } \\
t \text {-test }\end{array}$} & \multirow[b]{2}{*}{$d f$} & \multirow[b]{2}{*}{$p$} & \multirow[b]{2}{*}{ Cohen's $d$} \\
\hline & $\begin{array}{c}\text { Female } \\
(N=956)\end{array}$ & $\begin{array}{c}\text { Male } \\
(N=447)\end{array}$ & Female & Male & & & & \\
\hline $\begin{array}{l}\text { 1. Constructive } \\
\text { optimism }\end{array}$ & 4.08 & 3.81 & .76 & .94 & 5.34 & 724.8 & $\leq .001$ & .33 \\
\hline $\begin{array}{l}\text { 2. Defensive } \\
\text { optimism }\end{array}$ & 2.44 & 2.57 & .88 & .93 & -2.40 & 830.8 & .017 & .14 \\
\hline $\begin{array}{l}\text { 3. Dispositional } \\
\text { optimism }\end{array}$ & 2.51 & 2.25 & .73 & .69 & 6.30 & 918.2 & $\leq .001$ & .35 \\
\hline $\begin{array}{l}\text { 4. Autonomous } \\
\text { motivation }\end{array}$ & 5.66 & 5.04 & 1.31 & 1.55 & 7.35 & 754.4 & $\leq .001$ & .45 \\
\hline $\begin{array}{l}\text { 5. Controlled } \\
\text { motivation }\end{array}$ & 3.72 & 3.67 & 1.68 & 1.62 & .56 & 899.2 & .577 & .03 \\
\hline $\begin{array}{l}\text { 6. Adherence to } \\
\text { recommendation }\end{array}$ & 6.25 & 5.94 & 1.13 & 1.46 & 3.93 & 703.0 & $\leq .001$ & .25 \\
\hline 7. Positive affect & 2.99 & 2.94 & .74 & .82 & 1.22 & 801.7 & .223 & .07 \\
\hline 8. Negative affect & 2.64 & 2.44 & .83 & .86 & 4.07 & 847.9 & $\leq .001$ & .24 \\
\hline $\begin{array}{l}\text { 9. Satisfaction } \\
\text { with life }\end{array}$ & 3.25 & 3.29 & .73 & .72 & -1.04 & 885.8 & .300 & .06 \\
\hline 10. Happiness & 4.28 & 4.15 & 1.27 & 1.27 & 1.80 & 869.4 & .071 & .10 \\
\hline
\end{tabular}




\section{Structural Equation Modeling of Relations among Gender, Different Types of Optimism, and Health-Related Variables}

We applied structural equation modeling to analyze the overall effect of different types of optimism and motivation on following the recommendation to stay at home. Adherence to the recommendation was included in the model as a dependent variable, along with the factor of autonomous motivation as its main predictor and two factors of constructive and defensive optimism. Given the small effect of controlled motivation on adherence to the self-isolation recommendation and its weak correlations with different types of optimism, the factor of controlled motivation was not incorporated into the model. We expected that the effect of constructive and defensive optimism on adherence to the recommendation may be direct or mediated by autonomous motivation. On the basis of the observed correlations, we added to the model the factor of dispositional optimism (with an auxiliary orthogonal factor of response style needed for explaining shared variance of negatively worded items) as a predictor of constructive and defensive optimism. Last, we included gender as a predictor of all other variables to control for its effects. Estimation of this model showed that there were four insignificant parameters in spite of acceptable values of fit indices. After exclusion of these insignificant parameters, we obtained the model presented in the Figure 1 below, which had a satisfactory fit: $\chi^{2}=416.81 ; d f=125 ; p \leq .001$; CFI $=.946$; TLI $=.935$; RMSEA $=.041$ $(90 \% \mathrm{CI}=[.037, .045]), \mathrm{PCLOSE}=1, N=1,403$.

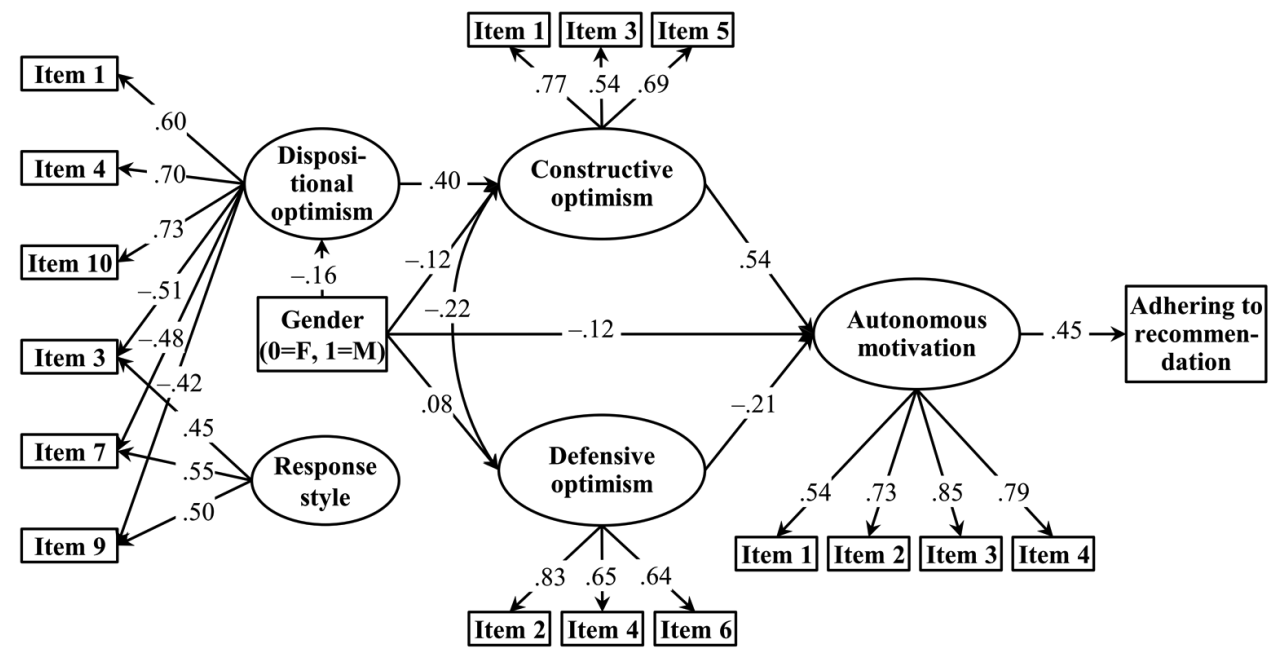

Figure 1. The structural model of relations among the different types of optimism, autonomous motivation, and adherence to the self-isolation recommendation, controlling for gender (all coefficients are standardized and significant at $\mathrm{p} \leq .05, \mathrm{~N}=1,403$ ).

Analysis of the indirect effects of different types of optimism and of gender on following the recommendation to stay at home in the presented structural model revealed that all tested effects were statistically significant (see Table 4). 
Table 4

Indirect effects of different types of optimism and gender on adherence to the recommendation of self-isolation

\begin{tabular}{llcc}
\hline \multicolumn{1}{c}{ Predictors } & \multicolumn{1}{c}{ Mediators } & $\begin{array}{c}\text { Standardized } \\
\text { indirect effect }\end{array}$ & \multicolumn{1}{c}{$\boldsymbol{p}$} \\
\hline Constructive optimism & Autonomous motivation & .24 & $\leq .001$ \\
Defensive optimism & Autonomous motivation & -.10 & $\leq .001$ \\
Dispositional optimism & $\begin{array}{l}\text { Autonomous motivation and constructive } \\
\text { optimism }\end{array}$ & .10 & $\leq .001$ \\
Gender & $\begin{array}{l}\text { Autonomous motivation, defensive optimism, } \\
\text { constructive optimism, and dispositional } \\
\text { optimism }\end{array}$ & -.11 & $\leq .001$ \\
\hline
\end{tabular}

Thus, the structural model reveals that adherence to the recommendation to stay at home depends on constructive situation-specific optimism, and underlying it, dispositional optimism via autonomous motivation. At the same time, the "adherence to the self-isolation recommendation" variable is inversely related to defensive optimism via autonomous motivation. The effect of gender on adherence to the recommendation is fully mediated by different types of optimism and autonomous motivation.

\section{Discussion}

We found that compliance with quarantine rules during the COVID-19 pandemic significantly depends on personality and motivational variables, primarily optimistic beliefs and autonomous motivation. Based on the literature on dispositional optimism, unrealistic optimism, and defensive pessimism, we differentiated two types of specific optimism in the context of the COVID-19 pandemic: constructive and defensive optimism. As predicted, we have shown that situation-specific optimistic beliefs may have different forms - constructive and defensive - with different motivational and behavioral consequences related to the COVID-19 pandemic. Constructive optimism includes belief in the importance of efforts for coping with problem and a sober assessment of its real difficulties, while defensive optimism implies "positive" underestimation of the problem and its denial.

With regard to the psychometric properties of the newly developed specific optimism measure, the results confirmed that it is a valid and reliable measurement instrument for assessing COVID-19-related optimism, demonstrating satisfactory internal consistency. The questionnaire showed satisfactory reliability of the scales and its two-factor structure was successfully confirmed using EFA and CFA. The two types of specific optimism were weakly negatively interrelated and showed opposite associations with general dispositional optimism and well-being.

Structural modeling showed that constructive and defensive optimism have the expected effects on the autonomous motivation to follow the recommendation to stay at home, and indirectly (via motivation) on real adherence to this recommendation. Both dispositional optimism and specific constructive optimism predict au- 
tonomous motivation and health-related behavior, while defensive optimism has the opposite, undermining, effects. The discovered gender differences in these two types of optimism provide a possible explanation for better adherence to the recommendations typical of women, confirmed by the results of structural modeling and analysis of indirect effects. Finally, our results on gender differences are consistent with those obtained by other researchers. In particular, Solomou and Constatinidou (2020) showed that males reported lower levels of compliance with precautionary measures.

Following previous research on self-control (Holding, Hope, Verner-Filion, \& Koestner, 2019), these results contribute to self-determination theory considering personality predictors, i.e., the role of generalized and specific optimism in autonomous motivation related to healthy behavior. Previous research in this field has mostly concentrated on environmental predictors of autonomous and controlled motivation.

\section{Conclusion}

Our results suggest that in addition to dispositional optimism, situation-specific constructive and defensive optimism are essential for explaining the health-related behavior. While constructive optimism supports adherence to the recommendation to stay at home via autonomous motivation, defensive optimism undermines it. These results contribute to self-determination theory, considering the role of personality factors in determining motivation.

\section{Implications and Limitations}

Our study has important practical implications. High dispositional optimism and constructive specific optimism and low defensive optimism impact the quality of motivation and promote adaptive health behavior during a pandemic. This means that support for realistic optimistic beliefs is recommended to mass media and public institutions, to promote both healthy attitudes and behavior. This is, of course, easier said than done, but doctors and the media should strive for a realistic and at the same time optimistic reflection of COVID-19 related events.

A limitation of this research was the participants' age, mostly under the age of 30. Prior studies showed that dispositional optimism tends to decline in older age (Gordeeva et al., 2021; Hinz et al., 2017), so the age-related changes in constructive and defensive optimism need further research. Also age was found to be a significant predictor of reactions to COVID-19-related stress (de Pedraza et al., 2020; Solomou \& Constantinidou, 2020), with young people suffering more (Pervichko et al., 2020). Future studies may benefit from considering whether constructive and defensive optimism are associated with changes in motivation quality and well-being over time. Thus, a longitudinal design is preferable in the future to understand the causal role of both dispositional and constructive optimism in COVID-related health behavior and well-being.

\section{Acknowledgements}

This research was supported by the Russian Foundation for Basic Research (Project No. 20-04-60174). 


\section{References}

Adams-Prassl, A., Boneva, T., Golin, M., \& Rauh, C. (2020). The impact of the coronavirus lockdown on mentalhealth:Evidencefrom the US(WorkingPapers2020-030). Human Capital andEconomicOpportunity Working Group. Retrieved from https://ideas.repec.org/p/hka/wpaper/2020-030.html

Agteren, J. van, Bartholomaeus, J., Fassnacht, D. B., Iasiello, M., Ali, K., Lo, L., \& Kyrios, M. (2020). Using Internet-based psychological measurement to capture the deteriorating community mental health profile during COVID-19: Observational study. JMIR Mental Health, 7(6), e20696. https://doi.org/10.2196/20696

Ahmed, M. Z., Ahmed, O., Aibao, Z., Hanbin, S., Siyu, L., \& Ahmad, A. (2020). Epidemic of COVID-19 in China and associated psychological problems. Asian Journal of Psychiatry, 51, 102092. https://doi.org/10.1016/j.ajp.2020.102092

Andersson, G. (1996). The benefits of optimism: A meta-analytic review of the Life Orientation Test. Personality and Individual Differences, 21(5), 719-725. https://doi.org/10.1016/0191-8869(96)00118-3

Arslan, G., \& Yildirim, M. (2020). Coronavirus stress, meaningful living, optimism, and depressive symptoms: A Study of Moderated Mediation Model (preprint). PsyArXiv. https://doi.org/10.31234/ osf.io/ykvzn

Balkhi, F., Nasir, A., Zehra, A., \& Riaz, R. (2020). Psychological and behavioral response to the coronavirus (COVID-19) pandemic. Cureus, 12(5), e7923. https://doi.org/10.7759/cureus.7923

Brodeur, A., Clark, A. E., Fleche, S., \& Powdthavee, N. (2020). Assessing the impact of the coronavirus lockdown on unhappiness, loneliness, and boredom using Google Trends. ArXiv:2004.12129. Retrieved from http://arxiv.org/abs/2004.12129

Brooks, S. K., Webster, R. K., Smith, L. E., Woodland, L., Wessely, S., Greenberg, N., \& Rubin, G. J. (2020). The psychological impact of quarantine and how to reduce it: Rapid review of the evidence. The Lancet, 395(10227), 912-920. https://doi.org/10.1016/S0140-6736(20)30460-8

$\mathrm{Bu}, \mathrm{D}$., Hanspal, T., Liao, Y., \& Liu, Y. (2020). Risk taking during a global crisis: Evidence from Wuhan (SSRN Scholarly Paper No. ID 3559870). Rochester, NY: Social Science Research Network. https://doi.org/10.2139/ssrn.3559870

Carver, C. S., \& Scheier, M. F. (2014). Dispositional optimism. Trends in Cognitive Sciences, 18(6), 293-299. https://doi.org/10.1093/med:psych/9780195119343.003.0009

Carver, C. S., Scheier, M. F., \& Segerstrom, S. C. (2010). Optimism. Clinical Psychology Review, 30(7), 879-889. https://doi.org/10.1016/j.cpr.2010.01.006

Colvin, C., \& Block, J. (1994). Do positive illusions foster mental health? An examination of the Taylor and Brown Formulation. Psychological Bulletin, 116(1), 3-20. https://doi.org/10.1037/00332909.116.1.3

COVID-19 pandemic in Russia. In Wikipedia, The Free Encyclopedia. Retrieved 14:02, July 22, 2020, from https://en.wikipedia.org/w/index.php?title=COVID-19_pandemic_in_Russia\&oldid=968943507

de Pedraza, P., Guzi, M., \& Tijdens, K. (2020). Life dissatisfaction and anxiety in COVID-19 pandemic (Working Paper No. 544). GLO Discussion Paper. Retrieved from https://www.econstor. eu/handle/10419/217053

Deci, E. L., \& Ryan, R. M. (2000). The 'what' and 'why' of goal pursuits: Human needs and the selfdetermination of behavior. Psychological Inquiry, 11(4), 227-268. https://doi.org/10.1207/ S15327965PLI1104_01

Diener, E., Emmons, R. A., Larsen, R. J., \& Griffin, S. (1985). The Satisfaction With Life Scale. Journal of Personality Assessment, 49(1), 71-75. https://doi.org/10.1207/s15327752jpa4901_13

Dufner, M., Gebauer, J. E., Sedikides, C., \& Denissen, J. J. A. (2019). Self-enhancement and psychological adjustment: A meta-analytic review. Personality and Social Psychology Review, 23(1), 48-72. https://doi.org/10.1177/1088868318756467

Dwyer, L. A., Bolger, N., Laurenceau, J.-P., Patrick, H., Oh, A. Y., Nebeling, L. C., \& Hennessy, E. (2017). Autonomous motivation and fruit/vegetable intake in parent-adolescent dyads. American Journal of Preventive Medicine, 52(6), 863-871. https://doi.org/10.1016/j.amepre.2017.01.011

Gallagher, M. W., Long, L. J., \& Phillips, C. A. (2020). Hope, optimism, self-efficacy, and posttraumatic stress disorder: A meta-analytic review of the protective effects of positive expectancies. Journal of Clinical Psychology, 76(3), 329-355. https://doi.org/10.1002/jclp.22882 
Gassman, S. M. (2019). The effect of optimism, basic psychological needs, and motivation type on exercise engagement ( $\mathrm{PhD}$ Thesis). The University of Nebraska-Lincoln.

Gillison, F., Sebire, S., \& Standage, M. (2012). What motivates girls to take up exercise during adolescence? Learning from those who succeed. British Journal of Health Psychology, 17(3), 536-550. https://doi.org/10.1111/j.2044-8287.2011.02053.x

Globig, L. K., Blain, B., \& Sharot, T. (2020). When private optimism meets public despair: Dissociable effects on behavior and well-being (preprint). PsyArXiv. https://doi.org/10.31234/osf.io/gbdn8

Goleman, D. J. (1989). What is negative about positive illusions? When benefits for the individual harm the collective. Journal of Social and Clinical Psychology, 8(2), 190-197. https://doi. org/10.1521/jscp.1989.8.2.190

Gordeeva, T. O., Sychev, O. A., \& Osin, E. N. (2021). Peresmotrennyi test dispozitsionnogo optimizma: validnost' i nadezhnost' russkoyazychnoi versii LOT-R [Revised version of Dispositional Optimism test: Validity and reliability of Russian version of LOT-R]. Psikhologia. Zhurnal Vysshei shkoly ekonomiki [Psychology. Journal of Higher School of Economics], 1.

Hagger, M. S., Hardcastle, S. J., Chater, A., Mallett, C., Pal, S., \& Chatzisarantis, N. L. D. (2014). Autonomous and controlled motivational regulations for multiple health-related behaviors: Betweenand within-participants analyses. Health Psychology and Behavioral Medicine, 2(1), 565-601. https://doi.org/10.1080/21642850.2014.912945

Halvari, A. E. M., \& Halvari, H. (2006). Motivational predictors of change in oral health: An experimental test of self-determination theory. Motivation and Emotion, 30(4), 294. https://doi. org/10.1007/s11031-006-9035-8

Hardy, S. A., Dollahite, D. C., Johnson, N., \& Christensen, J. B. (2015). Adolescent motivations to engage in pro-social behaviors and abstain from health-risk behaviors: A self-determination theory approach. Journal of Personality, 83(5), 479-490. https://doi.org/10.1111/jopy.12123

Harper, C. A., Satchell, L. P., Fido, D., \& Latzman, R. D. (2020). Functional fear predicts public health compliance in the COVID-19 pandemic. International Journal of Mental Health and Addiction, 1-14. Advance online publication. https://doi.org/10.1007/s11469-020-00281-5

Helmond, P., Overbeek, G., Brugman, D., \& Gibbs, J. C. (2015). A meta-analysis on cognitive distortions and externalizing problem behavior: Associations, moderators, and treatment effectiveness. Criminal Justice and Behavior, 42(3), 245-262. https://doi.org/10.1177/0093854814552842

Hinz, A., Sander, C., Glaesmer, H., Brähler, E., Zenger, M., Hilbert, A., \& Kocalevent, R.-D. (2017). Optimism and pessimism in the general population: Psychometric properties of the Life Orientation Test (LOT-R). International Journal of Clinical and Health Psychology, 17(2), 161170. https://doi.org/10.1016/j.ijchp.2017.02.003

Holding, A., Hope, N., Verner-Filion, J., \& Koestner, R. (2019). In good time: A longitudinal investigation of trait self-control in determining changes in motivation quality. Personality and Individual Differences, 139, 132-137. https://doi.org/10.1016/j.paid.2018.11.001

Hoyk, R., \& Hersey, P. (2010). The ethical executive: Becoming aware of the root causes of unethical behavior: 45 psychological traps that every one of us falls prey to. Stanford, CA: Stanford University Press.

Huang, Y., \& Zhao, N. (2020). Generalized anxiety disorder, depressive symptoms and sleep quality during COVID-19 outbreak in China: A web-based cross-sectional survey. Psychiatry Research, 288, 112954. https://doi.org/10.1016/j.psychres.2020.112954

Langer, E. J. (1975). The illusion of control. Journal of Personality and Social Psychology. 32(2), 311328. https://doi.org/10.1037/0022-3514.32.2.311

Lei, L., Huang, X., Zhang, S., Yang, J., Yang, L., \& Xu, M. (2020). Comparison of prevalence and associated factors of anxiety and depression among people affected by versus people unaffected by quarantine during the COVID-19 epidemic in Southwestern China. Medical Science Monitor: International Medical Journal of Experimental and Clinical Research, 26, e924609-1-e924609-12. https://doi.org/10.12659/MSM.924609

Lyubomirsky, S., \& Lepper, H. S. (1999). A measure of subjective happiness: Preliminary reliability and construct validation. Social Indicators Research, 46(2), 137-155. https://doi. org/10.1023/A:1006824100041 
McSpadden, K. E., Patrick, H., Oh, A. Y., Yaroch, A. L., Dwyer, L. A., \& Nebeling, L. C. (2016). The association between motivation and fruit and vegetable intake: The moderating role of social support. Appetite, 96, 87-94. https://doi.org/10.1016/j.appet.2015.08.031

Muthén, L. K., \& Muthén, B. O. (2015). Mplus user's guide (eighth edition). Los Angeles, CA: Muthén \& Muthén.

Nes, L. S., \& Segerstrom, S. C. (2006). Dispositional optimism and coping: A meta-analytic review. Personality \& Social Psychology Review, 10, 235-251. https://doi.org/10.1207/s15327957pspr1003_3

Ng, J. Y. Y., Ntoumanis, N., Thøgersen-Ntoumani, C., Deci, E. L., Ryan, R. M., Duda, J. L., \& Williams, G. C. (2012). Self-determination theory applied to health contexts: A meta-analysis. Perspectives on Psychological Science, 7(4), 325-340. https://doi.org/10.1177/1745691612447309

Norem, J. K. (2008). Defensive pessimism, anxiety, and the complexity of evaluating self-regulation. Social and Personality Psychology Compass, 2(1), 121-134. https:// doi.org/10.1111/j.1751-9004.2007.00053.x

Norem, J., \& Cantor, N. (1986). Defensive pessimism: Harnessing anxiety as motivation. Journal of Personality and Social Psychology, 51(6), 1208-1217. https://doi.org/10.1037/0022-3514.51.6.1208

Osin, E. N. (2012). Izmerenie pozitivnykh i negativnykh emotsii: razrabotka russkoyazychnogo analoga metodiki PANAS [Measuring positive and negative affect: Development of a Russianlanguage analogue of PANAS]. Psikhologia. Zhurnal Vysshei shkoly ekonomiki [Psychology. Journal of Higher School of Economics], 9(4), 91-110.

Osin, E. N., \& Leontiev, D. A. (2020). Kratkie russkoyazychnye shkaly diagnostiki sub"ektivnogo blagopoluchiya: psikhometricheskie kharakteristiki i sravnitel'nyi analiz [Brief Russian-language instruments to measure subjective well-being: Psychometric properties and comparative analysis]. Monitoring obshchestvennogo mneniya: ekonomicheskie i sotsial'nye peremeny [Monitoring of Public Opinion: Economic and Social Changes], 1(156), 117-142. https://doi.org/10.14515/ monitoring.2020.1.06

Patrick, H., \& Williams, G. C. (2012). Self-determination theory: Its application to health behavior and complementarity with motivational interviewing. International Journal of Behavioral Nutrition and Physical Activity, 9(1), 18. https://doi.org/10.1186/1479-5868-9-18

Pervichko, E. I., Mitina, O. V., Stepanova, O. B., Koniukhovskaia, J. E., \& Dorokhov, E. A. (2020). Vospriyatie COVID-19 naseleniem Rossii v usloviyakh pandemii 2020 goda [Perception of COVID-19 during the 2020 pandemic in Russia]. Klinicheskaia $i$ spetsialnaia psikhologiya [Clinical Psychology and Special Education], 9(2), 119-146. https://doi.org/10.17759/cpse.2020090206

Rasskazova, E. I., Leontiev, D. A., \& Lebedeva, A. A. (2020). Pandemiya kak vyzov sub"ektivnomu blagopoluchiyu: trevoga i sovladanie [Pandemic as a challenge to subjective well-being: Anxiety and coping]. Konsul'tivnaya psikhologiya i psikhoterapiya [Counseling Psychology and Psychotherapy], 28(2), 90-108. https://doi.org/10.17759/cpp.2020280205

Ryan, R. M., \& Deci, E. L. (2000). Intrinsic and extrinsic motivations: Classic definitions and new directions. Contemporary Educational Psychology, 25(1), 54-67. https://doi.org/10.1006/ ceps. 1999.1020

Ryan, R. M., \& Deci, E. L. (2017). Self-determination theory: Basic psychological needs in motivation, development, and wellness. New York, NY: Guilford Publications.

Scheier, M. F., \& Carver, C. S. (1985). Optimism, coping, and health: Assessment and implications of generalized outcome expectancies. Health Psychology: Official Journal of the Division of Health Psychology, American Psychological Association, 4(3), 219-247. https://doi. org/10.1037/0278-6133.4.3.219

Scheier, M. F., Carver, C. S., \& Bridges, M. W. (1994). Distinguishing optimism from neuroticism (and trait anxiety, self-mastery, and self-esteem): A reevaluation of the Life Orientation Test. Journal of Personality and Social Psychology, 67(6), 1063-1078. https://doi. org/10.1037/0022-3514.67.6.1063

Seligman, M. E. P. (2011). Learned optimism: How to change your mind and your life. Vintage.

Shaikh, A. R., Yaroch, A. L., Nebeling, L., Yeh, M.-C., \& Resnicow, K. (2008). Psychosocial predictors of fruit and vegetable consumption in adults: A review of the literature. American Journal of Preventive Medicine, 34(6), 535-543. https://doi.org/10.1016/j.amepre.2007.12.028

Sharot, T. (2012). The optimism bias: Why were wired to look on the bright side. Hachette UK. 
Sheldon, K. M., Osin, E. N., Gordeeva, T. O., Suchkov, D. D., \& Sychev, O. A. (2017). Evaluating the dimensionality of self-determination theory's relative autonomy continuum. Personality and Social Psychology Bulletin, 43(9), 1215-1238. https://doi.org/10.1177/0146167217711915

Silva, M. N., Markland, D., Carraça, E. V., Vieira, P. N., Coutinho, S. R., Minderico, C. S., .. Teixeira, P. J. (2011). Exercise autonomous motivation predicts 3-yr weight loss in women. Medicine and Science in Sports and Exercise, 43(4), 728-737. https://doi.org/10.1249/MSS.0b013e3181f3818f

Solomou, I., \& Constantinidou, F. (2020). Prevalence and predictors of anxiety and depression symptoms during the COVID-19 pandemic and compliance with precautionary measures: Age and sex matter. International Journal of Environmental Research and Public Health, 17(14), 4924. https://doi.org/10.3390/ijerph17144924

Stanton, R., To, Q. G., Khalesi, S., Williams, S. L., Alley, S. J., Thwaite, T. L., ... Vandelanotte, C. (2020). Depression, anxiety and stress during COVID-19: Associations with changes in physical activity, sleep, tobacco and alcohol use in Australian adults. International Journal of Environmental Research and Public Health, 17(11), 4065. https://doi.org/10.3390/ijerph17114065

Taylor, S. E., Kemeny, M. E., Reed, G. M., Bower, J. E., \& Gruenewald, T. L. (2000). Psychological resources, positive illusions, and health. The American Psychologist, 55(1), 99-109. https://doi. org/10.1037//0003-066x.55.1.99

Verloigne, M., De Bourdeaudhuij, I., Tanghe, A., D’Hondt, E., Theuwis, L., Vansteenkiste, M., \& Deforche, B. (2011). Self-determined motivation towards physical activity in adolescents treated for obesity: An observational study. International Journal of Behavioral Nutrition and Physical Activity, 8(1), 97. https://doi.org/10.1186/1479-5868-8-97

Wang, C., Pan, R., Wan, X., Tan, Y., Xu, L., Ho, C. S., \& Ho, R. C. (2020). Immediate psychological responses and associated factors during the initial stage of the 2019 coronavirus disease (COVID-19) epidemic among the general population in China. International Journal of Environmental Research and Public Health, 17(5), 1729. https://doi.org/10.3390/ijerph17051729

Watson, D., Clark, L. A., \& Tellegen, A. (1988). Development and validation of brief measures of positive and negative affect: The PANAS scales. Journal of Personality and Social Psychology, 54(6), 1063-1070. https://doi.org/10.1037/t03592-000

Original manuscript received July 11, 2020

Revised manuscript accepted September 25, 2020

First published online December 01, 2020

To cite this article: Gordeeva, T.O., Sychev, O.A., Semenov, Yu.I. (2020). COVID-19: Constructive Optimism, Defensive Optimism, and Gender as Predictors of Autonomous Motivation to Follow Stay-at-Home Recommendations During the COVID-19 Pandemic. Psychology in Russia: State of the Art, 13(4), 38-54. DOI: 10.11621/pir.2020.0403 